\title{
The Research on the Model of SOE Corporate CSR Budget Management for Optimizing Disaster Management
}

\author{
(Covid-19 Case Study in North Sumatra Province)
}

\author{
Azizul Kholis ${ }^{1, *}$, Dedy Husrizal Syah ${ }^{1}$, Sulaiman Lubis ${ }^{1}$, Lukitaningsih ${ }^{1}$ \\ ${ }^{1}$ Universitas Negeri Medan \\ *Corresponding author.Email: azizulkholis@unimed.ac.id
}

\begin{abstract}
In Indonesia, disaster management is regulated in Law number 24 of 2007 concerning Disaster Management. Three levels or phases of emergency situations have been defined in order to identify the level of impact and response required for both disaster preparedness and disaster emergency depending on the situation that occurs. This condition is clearly in line with the objective of the emergency response plan, which is to establish standard operating procedures in order to mobilize resources, especially financial. to help ease the burden on local government budgets. One of the potential funds that can help for disaster funds is the Corporate Social Responsibility (CSR) budget for state-owned enterprises (BUMN). The potential for corporate CSR funds in North Sumatra is very large because there are nearly 50 state-owned companies operating in North Sumatra. This study aims to find out the amount of CSR funds of BUMN companies managed in North Sumatra province, and how much is allocated for disasters, CSR programs and activities. potential for cooperation between BUMN companies and The Government of North Sumatera Province (Pemprovsu) to be more optimal for disaster relief.
\end{abstract}

Keywords: CSR, Covid-19, BUMN

\section{INTRODUCTION}

The issue of disasters is the most important part that must be considered because based on the international disaster data base in the last 10 years since 2010, disasters have killed more than 295,000 people and more than US $\$ 150.9$ billion in economic losses [48]. Since the World Health Organization (WHO) declared Covid-19 a pandemic on March 11, 2020, all countries including Indonesia have implemented various prevention and special handling efforts.

This template, modified in MS Word 2007 and saved as The Covid-19 pandemic disaster in Indonesia has officially been determined with a public health emergency. The policy taken is to establish Large-Scale Social Restrictions (PSBB), as a policy to limit the movement of people and goods. The policy is stipulated through Government Regulation no. 21 of 2020 and its implementation is regulated in the Regulation of the Minister of Health of the Republic of Indonesia Number
9 of 2020. The Covid-19 pandemic facing the Indonesian nation is a major disaster that is being faced.

In Indonesia, disaster has been regulated in Law Number 24 of 2007 concerning Disaster Management, which regulates the level of seriousness of a disaster in stages. Three levels or phases of emergency situations have been defined in order to identify the level of impact and response required for both disaster preparedness and disaster emergency depending on the situation that occurs. This condition is clearly in line with the purpose of the emergency response plan, which is to establish standard operating procedures in order to mobilize resources, especially financial. The government itself does have disaster funds that have been allocated each year, but because disasters cannot be predicted with certainty, the government often experiences constraints on limited funds available for handling a disaster.

According to a study by the National Disaster Management Agency, the number of casualties and the obstruction of various activities during a disaster, one of 
which is due to a lack of budget and emergency funds for disaster management. Research by [47] which was carried out after the disaster, stated that the number of casualties in a disaster that occurred was one of them due to lack of logistics, medicine and lack of budget and how the implementation of disaster management must be carried out and the emergency attitude that must be had. by the community.

North Sumatra Province is an area with a high risk of disaster, because based on the results of a BPBD (2018), North Sumatra has 12 types of disasters such as earthquakes, flash floods, landslides, tornadoes, volcanoes, tsunamis and others. Most of the districts / cities in North Sumatra are also included in the 136 districts / cities in Indonesia which are disaster-prone areas. Especially for handling Covid-19, the Provincial Government has allocated a budget through the Regional Apparatus Organization (OPD) for the health and nonhealth sectors. In detail, it can be seen in Table 1 (one) below:

Table 1 Re-Focusing of Pemprovsu's Budget for Covid-19

\begin{tabular}{ll} 
No & Regional device organization \\
\hline 1 & BPBD \\
2 & Public health Office \\
& Total
\end{tabular}

Source: Covid's Task Force of Pemprovsu, 2020

The funds in table 1 (one) above are sourced from the 2020 Regional Budget Refocusing carried out by the North Sumatra Provincial Government. The funds have been channelled to the Regional Disaster Management Agency (BPBD) for more than Rp. 32 billion and to the Health Office in the amount of Rp. 199 billion. This allocation is used for activities that fund health and nonhealth functions used by GTPP. In total, the North Sumatra Provincial Government has also allocated a budget of more than IDR 1.5 trillion for the response to Covid-19. The funds are allocated into 3 stages. In the first stage, a budget of IDR 502 billion is allocated, the second stage is IDR 500 billion and the third stage is IDR 500 billion. This budget allocation has an impact on the efficiency of spending on routine activities, for example for meetings, meetings, socialization activities, including official travel. Apart from health, Covid-19 also has an impact on the social and economy of the community. The North Sumatra Provincial Government has prepared a budget for the Social Safety Net (JPS). This assistance will be given to 150 thousand heads of families with an income of IDR 600 thousand per month.

One of the potential funds that can help for disaster funds is the Corporate Social Responsibility (CSR) budget for state-owned enterprises (BUMN). The potential for corporate CSR funds in North Sumatra is very large because there are almost 50 state-owned companies operating in North Sumatra and there are 5 (five) BUMNs having their head office directly, namely PT. Inalum, PT. Pelindo I, PT. Perkebunan Nusantara, 2 (two), PTPN 3 (three) and PTPN 4 (four), the rest are headquartered in Jakarta but have representatives or branches in North Sumatra.

The potential for the CSR budget of BUMN companies is very possible to help disaster funds because currently there are at least 7 (seven) regulations related to corporate social responsibility in the form of laws, government regulations, and ministerial regulations.
Many regulations at the provincial and district / city government levels have also been issued in the form of regional regulations or CSR regulations. At least more than 50 districts / cities in Indonesia have issued CSR regulations, but it is very unfortunate that the North Sumatra Provincial Government does not yet have a regional regulation or a CSR regulation. Likewise, 33 municipalities throughout North Sumatra, all of which do not have regulations related to CSR in their respective areas, even though the potential is very large, especially helping disaster activities. This can happen because there is no study on the importance of these regulations to be published in the regions.

Then also no party took the initiative to conduct academic studies for policy recommendations to the local government for the intended regulatory regulation. In fact, if the Provincial Government wants to issue these regulations, there are seven legal umbrella for CSR regulations in Indonesia which can be used as a basis and guidelines as detailed in table 2 below:

The provincial government will make the stages of using a budget of IDR 270 billion. "Then there is also food aid from GTPP of around Rp. 30 billion, so a total of Rp. 300 billion. However, some obstacles in managing disaster funds are (1) budget constraints, (2) ) budget management rules, and (3) budget accountability. The government usually cannot divert a budget without going through a mechanism that has been regulated in a regulation, such as the Minister of Finance Regulation and the Minister of Home Affairs Regulation on APBD management. Even though in an emergency situation, it is necessary to accelerate activities so that budget constraints must be found for solutions. Based on the aforementioned facts, it can be clearly stated that the limited disaster management budget experienced by local governments must find a solution, for example involving the private sector or the public to contribute funds to help ease the burden on the Regional Government budget. 
However, it is recognized that only a small number of companies have implemented CSR, as the results of a survey conducted by Suprapto in 2005 of 375 companies in Jakarta showed that 166 or $44.25 \%$ of companies stated that they did not carry out CSR activities, 209 or $55.75 \%$ stated that they carried out CSR activities in the form of activities as follows: family activities (116 companies), donations to religious institutions (50 companies), donations to social institutions (39 companies), and community development (4 companies). The main problem is that up to now the Province of North Sumatra does not have a Governor Regulation or perda on CSR so that the optimization of CSR fund management does not have a good management model. For this reason, this research is very urgent to do by exploring the potential of CSR in BUMN companies to be recommended in the form of policies that can be issued by the Provincial Government.

In addition, the problem of implementing the CSR budget management model for BUMN Companies is to optimize disaster management, because with this research it is possible to create a CSR fund management model for BUMN companies to be more coordinated effectively, right on target, not overlapping, efficient in their use. and become more optimal. Based on the background description above, there are several problems that can be identified in this study, namely:

1. North Sumatra Province is an area that has a lot of disaster prone areas. The Provincial

2. Government has limited disaster budgets sourced from the APBD.

3. Cost countermeasures for the Covid19 pandemic in the Task Force are very large so it must refocusing on the budget.

4. There is no data on the potential for CSR funds managed by state-owned companies operating in North Sumatra.

5. The data on potential CSR funds that can be cooperated for disaster relief is not yet known. The budget model and programs and what forms of activities can be funded through CSR fund management are not yet known. BUMN companies to the Regional Government

6. There is no cooperation forum for the management of CSR of BUMN companies with various parties in North Sumatra.

7. There is no regulation of governors or regional regulations for the implementation of CSR activities in a sustainable manner issued by PemPemprovsu.

\subsection{Formulation of The Problem}

Based on the identification of the problems mentioned above, the formulation of the proposed research problem is:
1. How much is the potential for CSR funds managed by state-owned companies in North Sumatra province?

2. How much is the potential for CSR funds managed by state-owned companies in North Sumatra province for disaster relief?

3. What CSR programs and activities have the potential for cooperation between BUMN companies and Pemprovsu?

4. What is the CSR budget management model for BUMN companies to be more optimal for disaster relief?

5. What draft recommendations on regulations is required by Pemprovsu regarding CSR funds in North Sumatra?

\section{LITERATURE REVIEW}

\subsection{Stake holder Theory}

Stake holder theory explains that each group or individual can influence the achievement of organizational goals. This theory states that the success and survival (going corncern) of a company is very much dependent on its ability to balance the various interests of the stakeholders. Stakeholders who are the focus of the achievement of corporate social performance have a major role in maximizing business profits. The model stake holder described in much of the literature can be illustrated in Figure 1 as follows:

STAKEHOLDER MODEL

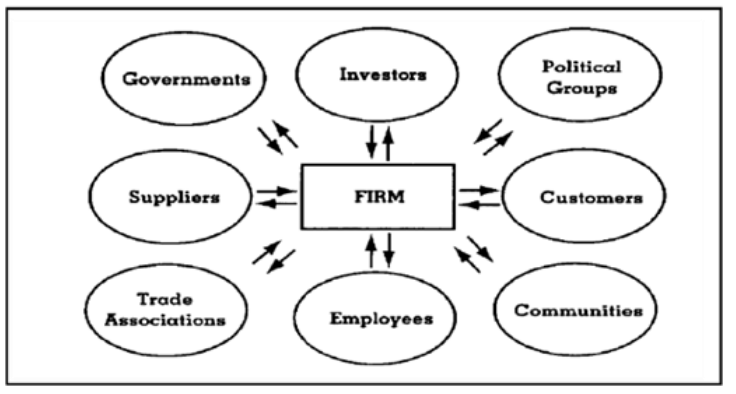

Figure 1. Stakeholder Model

\subsection{Corporate Social Responsibility (CSR)}

CSR is a business commitment to play a role in economic development that can work with employees and their representatives, the surrounding community and the wider community to improve the quality of life, in a way that is good for business and development. Definition of CSR according to the International Finance Corporation (IFC), 2000: "The commitment of the business world to contribute to sustainable economic development by collaborating with employees, their families, local communities and the wider community to improve their lives in ways that are good for business and business. development. ISO 26000, regarding Guidance on Social Responsibility, defines CSR as follows: "The responsibility of an organization for the impacts of its 
decisions and activities on society and the environment which is manifested in transparent and ethical behavior in line with sustainable development and welfare. society, taking into account stakeholder expectations, in line with established laws and international norms of behavior, and integrated with the organization as a whole. The definition of Corporate Social Responsibility is very diverse, depending on the corporate vision and mission that is tailored to the needs, desires and interests of the community. Until now, there has not been a single definition of Corporate Social Responsibility that has been accepted globally. Etymologically, it can be interpreted as Corporate or Corporate Social Responsibility. According to Article 1 point 3 of Law no. 40 of 2007 concerning Limited Liability Companies, Corporate Social Responsibility is defined as the company's commitment to participate in sustainable economic development in order to improve the quality of life and the environment that is beneficial, both for the company itself, the local community, and society in general.

\subsection{Previous Research}

A study by the National Disaster Management Agency states that the number of casualties and the obstruction of various activities during a disaster is due to the community's lack of understanding in responding to the disaster.

Research by [47] which was carried out after the disaster, stated that the number of casualties in a disaster that occurred was one of them due to lack of logistics, medicine and lack of budget and how the implementation of disaster management must be carried out and the emergency attitude that must be had. by the community.

The North Sumatra Province study is an area with a high risk of disasters, because based on the results of the BPBD Pemprovsu study, in North Sumatra there are 12 types of disasters such as earthquakes, flash floods, landslides, tornadoes, volcanoes, tsunamis and others.

\section{RESEARCH METHODS}

This research was conducted in Medan City, Deli Serdang Regency, Batubara Regency and Simalungun Regency because of the domicile of BUMN representative offices in North Sumatra Province. The time of this research is planned for 3 (three) months starting from June to August 2020. The population in this study is all BUMN companies in North Sumatra Province, the total number of PMDN is 50 BUMN companies. This study does not use a sample technique, but uses a census method, which is to make all members of the population as research subjects. This research was conducted in a network (online / online). Data collection was carried out using various online / online applications and the use of social media, namely WhatsApp, Facebook, Instagram and Twitter. The research questionnaire was distributed using the application Google form which was distributed to all companies in the province of North Sumatra by sending access to the company's website and to various WA groups, personal email, private chat and all owned social media. And some are sent by post.

The data analysis technique in this study was carried out in several stages, namely: The first stage all data was tabulated and then analyzed with a descriptive statistical approach, namely looking at the mean, median, mode and cumulative values of the data obtained both in absolute numbers and percentage levels. The data calculated using the descriptive statistical approach were processed with the help of statistical software SPSS version 21, and then presented in graphical form.

The formula used is to calculate the company's CSR cost index, namely:

BUMN CSR Cost Index =

\section{$\frac{\text { Jlh.Average Unit Cost }}{\text { Total CSR Costs Per Year }}$ X 100\%}

To test whether there is repetition and overlap between one component of the CSR program funds based on the cost index, the Run Test is a part of non-parametic statistics and can also be used to test whether there is a high correlation between residuals. With the test criteria: If there is no correlation between residuals, it is said that the residuals are random or random. Run test is used to see whether the residual data occurs randomly or not (systematically):

\section{H0: residual (res_1) random}

Ha: residual (res_1 is not random.

With the basic hypothesis above, the basis for making statistical test decisions with the Run Test is [15]: If the Asymp.Sig (2-tailed) value is less than 0.05, then $\mathrm{HO}$ is rejected and $\mathrm{Ha}$ is accepted. This means that the residual data is not random (systematic). If the Asymp.Sig (2tailed) value is more than 0.05 , then $\mathrm{H} 0$ is rejected and $\mathrm{Ha}$ is rejected. This means that the residual data occurs randomly (random). This test uses the application Partial Least Square (PLS).

The second stage, all data that has been presented in graphical form, is discussed by the research team to make a justification for the explanation of the data for making research conclusions. After discussion and justification from the research team, in the third stage the results of the research are discussed in more depth with relevant parties in a focused discussion forum (Focus Group Discussion).

\section{RESULTS AND DISCUSSION}

This study was conducted on July 20 to September 20 2020 with several data dissemination processes, first distributing questionnaires via google form, directing questionnaires directly to company offices and sending questionnaires via postal services to BUM companies. In this study, the population used is state-owned companies. BUMN companies are companies that are owned either wholly or partly by the government and the government exerts control over them. The research sample used is a 
state-owned company operating in North Sumatra, which consists of 50 companies.

Data collection in the study was carried out in several stages, namely, by distributing 40 questionnaires to respondents in the North Sumatra region consisting of state-owned companies. All the questionnaires that were distributed were $85 \%$ returned and picked up according to a predetermined time limit.

Corporate Social Responsibility (CSR) or the equivalent of social responsibility in Indonesia initially appeared in developed countries as an inseparable aspect of a business company. In developed countries themselves, CSR includes corporate social responsibility for employees or employees and employees' families. However, the general public understand more about CSR as an externally responsible field, that is, the focus of its activities is related to company assistance and community empowerment programs.

Results of this study prove that CSR (Corporate Social Responsibility) originating from state-owned companies is mostly allocated for disaster management such as the COVID-19 pandemic. 19. It is the duty of every company to implement Corporate Social Responsibility (CSR) and include its budget for disaster management. The amount of the budget and the form of its activities are the rights of every company.

The CSR model or pattern commonly applied by companies in Indonesia, namely First, CSR can be implemented directly by the company. Second, CSR can also be implemented by foundations or social organizations owned by companies or their groups. Third, most companies in Indonesia carry out CSR through cooperation or in partnership with other parties. Fourth, several companies joined in a consortium to jointly carry out CSR.

Indonesia itself has made it mandatory for all companies, especially state-owned companies, to implement CSR programs, while for other companies the obligation to implement CSR is limited to a moral obligation. However, along with the development of science and business strategy, the CSR program is part of the aspects that determine the sustainability of a business company and the existence of CSR is one of the aspects that benefit the company. Referring to the theory of motives for implementing CSR, there are motives called political theories, this motive understands CSR as an inherent obligation along with the ownership of power and power of a company.

Judging from the CSR patterns described, it can be seen that every CSR activity carried out by BUMN companies includes all the patterns previously described. Several companies are directly involved in the implementation including the provision of financial assistance as sponsorship is a pattern or model of providing assistance directly without going through intermediaries.
There are three forms of CSR implementation, namely; (1) Community Relations, the company only provides assistance that the community feels is needed from the company's subjective point of view. In other words, the company provides what the company wants to provide as assistance (2) Community Assistance, providing assistance taking into account the needs that the community really needs. In this case, the company conducts an assessment of the condition of the community and provides what the community needs in accordance with the results of the assessment. (3) Community Empowerment, is a CSR implementation that empowers the community with assistance provided by the company.

Since the spread of the COVID-19 pandemic in Indonesia, the Minister of BUMN has instructed every state-owned company to focus CSR funds on handling covid-19.

\section{CONCLUSION}

The title "ACKNOWLEDGMENTS" should be in all caps and should be placed above the references. The references should be consistent within the article and follow the same style. List all the references with full details.

\section{REFERENCES}

[1] Anderson and King. Mitigation of the Impact of Tropical Cyclones in Northern Australia through Community Capacity Enhancement. Volume 10, Issue 3, 2005, pp 367-392.

[2] Aristha Purwanthari Sawitri dan Fauziyah, Peran Akuntan Pendidik dalam Meningkatkan Profesionalisme Calon Akuntan. Jurnal Studi Manajmen dan Bisnis, Prodi MM Universitas Trunojoyo, Madura. 2017.

[3] Azizul Kholis, Faktor Penentu Profeswionalisme Dosen Akuntansi, Proseeding, Simposium Nasional penelitian dan Kebijakan Pendidikan, Departemen Pendidikan nasional RI, Jakarta. 2012.

[3] Badan Nasional Penanggulangan Bencana. Peraturan Kepala Banda Nasional Penanggulangan Bencana Nomor 1 Tahun 2012 tentang Pedoman Umum Desa/Kelurahan Tangguh Bencana. BNPB. 2012

[4] Catherine L. Mann. Real and financial lenses to assess the economic consequences of COVID-19 A CEPR Press VoxEU.org eBook, CEPR Press. ISBN: 978-1-912179-28-2, 2020. Web: www.cepr.org

[5] Dian Agustia, Kesiapan Profesi Akuntan pendidik Indonesia dalam era Distrupsi dan memasuki Revolusi industry 4.0, Simpisum Ilmiah Akuntansi, IAI KPd Wilayah Sumut, Universitas Methodist Indonesia. 2019

[6] Dirjen Dikti Kemendibud RI, Surat edaran nomor :302/E.E2/KR/2020 tanggal 31 Maret 2020 Enny 
Susilowati Mardjono dan Baningatus Solikhan, 2014. Profesionalisme Akuntan Pendidik :

[7] Perspektif Atau Triger Kualitas Lulusan Akuntansi Di Era Masyarakat Ekonomi Asean,

[8] Jurnal Akuntansi \& Auditing Volume 11/No. 1/ November 2014: pp 103 - 1191.

[9] Ella dan Usman. Mencerdasi Bencana, Penerbit Grasindo, Jakarta. 2008.

[10] Fajar Nursaid, CSR Bidang Kesehatan dan Pendidikan Mengembangkan Sumber Daya Manusia, Cetakan pertama, Jakarta: Indonesia Business Link. 2008.

[11] Friedman, Stakeholder Theory: Approach for bussisnes and Social performance, Springer Publisher, Newyork,USA. 2007.

[12] Hall. Conceptual framework of Stake holder Theory: based on Friedman Model, Willey Inc, Publisher, USA. 2015.

[13] International Monetary Fund, Global Financial Stability Report, Washington DC. 2019.

[14] Irman Oemar, Perlukah Sumut memberlakukan PSBB, Artikel opini, harian Waspada, terbitan 27 Maret 2020, akses online http://www. waspadaonline.co.id

[15] Ghozali, Imam. Aplikasi Analisis Multivariete Dengan Program SPSS 23 (Edisi 8). Cetakan ke VIII. Semarang: Badan Penerbit Universitas Diponegoro. 2016.

[16] Ghozali, Imam. Analisis statistic menggunakan aplikasi Wrap PLS (Edisi 8). Cetakan ke I, Semarang: Badan Penerbit Universitas Diponegoro. 2018.

[17] Gunawan. Kondisi Sosial Masyarakat dalam Manajemen Bencana. Yogyakarta. 2008.

[18] Kitindi, E. G. and Mgaya, K. V. 'Essential skills needed by accounting graduates in a developing country: the views of practicing accountants and accounting educators in Botswana', in Foong, S.Y. and Noghondari, A.T. (eds). International Journal: Accounting, Auditing and Performance Evaluation, 5(3):2009, pp 329-349.

[19] Kemendikbud RI, Surat Edaran Nomor 4 Tahun 2020 tentang Pelaksanaan Pendidikan Dalam Masa Darurat Corona virus Disease (Covid-19) akses pada www.kemendikbud,go.id

[20] Keputusan Menteri PMDN No.:Kep236/MBU/2003 tentang Program Kemitraan PMDN dengan Usaha Kecil dan Program Bina Lingkungan

[21] Keputusan Menteri Keuangan No.: 316/KMK.016/1994 tentang Pedoman Pembinaan Usaha Kecil dan Koperasi melalui Pemanfaatan Dana dari Bagian Laba Badan Usaha Milik Negara.
[22] Keputusan Menteri Keuangan No.:1232/KMK.013/1989 tentang Pedoman Pembinaan Pengusaha Ekonomi Lemah dan Koperasi melalui Badan Usaha Milik Negara.

[23] Keputusan Menteri Negara Pendayagunaan PMDN/Kepala Badan Pembina PMDN No.: Kep216/M-PPMDN/1999 tentang Program Kemitraan dan Bina Lingkungan PMDN

[24] Lewis Wren Simon, Pandemi Impact of Economic, A CEPR Press VoxEU.org eBook, CEPR Press. ISBN: 978-1-912179-28-2, 2020. Web: www.cepr.org

[25] Lembaga Ilmu Pengetahuan Indonesia SCO/ISDR. Sebuah Kajian dan Studi tentang Kesiapsiagaan Masyarakat dalam Mengantisipasi Bencana Gempa Bumi dan Tsunami. Deputi Ilmu Pengetahuan Kebumian Lembaga Ilmu Pengetahuan Indonesia. Jakarta. 2006

[26] Lethbene Jocobine, Improving grade 10 accounting teachers' competencies in the ekurhuleni district of the gauteng provincebym, Theses, University of South Africa. 2014.

[27] Maheran, Z., Wan Noor Asmuni, F. \& Hasan, S.J. 'Accounting as a choice of academic program', Journal of Businesses Administration Research, 1(1): 2012. Pp 43-52. [online]. Available at: http://dx.dx.doi.org/10.5430/jbar.v/n/p43>[Accesse d15 January 2013]

[28] Marvin 1. Birnbaum md, Elaine Daily, "Health Disaster Management", University of Wisconsin school of Medicine and Public Health, Madison Past President, the World Association for Disaster and Emergency Medicine. 2012.

[29] Mas Nur Mukmin dan Hesti Wulansari, Akuntabilitas Kinerja Akuntan Pendidik Berdasarkan Kompetensi Akuntan Dan Etika Profesional (Studi Empiris Pada Perguruan Tinggi Swasta Di Bogor) Jurnal Akunida ISSN 2442-3033 Volume 3 Nomor 2, Desember 2017 DOI: 10.30997/jakd.v3i2.979,

[30] Mulya Amri, Wicaksono Sarosa, CSR Untuk Penguatan Kohesi Sosial, Cetakan Pertama, Jakarta: Indonesia Business Links. 2008.

[31] Paisey, C.,Paisey, N. \&Tarbert, H., 'Continuing professional development activities of UK accountants in public practice', in Wessels, B.S. (ed). Accounting Education: An International Journal,16(4): 2007, pp 379-403.

[32] Peraturan Pemerintah No 21 tahun 2020 tentang Pembatasan Sosial Berskala Besar (PSBB), Menteri Sekretaris Negara RI, Jakarta akses pada www.setneg,go.id

[33] Permenkes No. 9 Tahun 2020 tentang mekanisme Pembatasan Sosial Berskala Besar (PSBB), 
Kementerian Kesehatan RI, Jakarta, akses pada www.kemenkes,go.id

[34] Panglaykim, Jusuf, State Enterprises: Recent of Development, Bulletin of Indonesian Economic Studies, No 9, Jakarta. 1968.

[35] Peraturan Pemerintah Nomor 32 Tahun 1998 tentang Pembinaan dan Pengembangan Usaha Kecil.

[36] Peraturan Menteri Negara PMDN No.: Per05/MBU/2007 tentang Program Kemitraan PMDN dengan Usaha Kecil dan Program Bina Lingkungan.

[37] Poser, K. \& Dransch, D., Volunteered geographic information for disaster management with application to rapid flood damage estimation. Geomatica, 64(1), 2010. pp: 89-98.

[38] Priyanto, A., Promosi Kesehatan Pada Situasi Emergensi Edisi 2. Jakarta. 2006.

[39] PSB-UGM. Reorientasi Pendidikan Kebencanaan dalam Rangka Pengurangan Risiko Bencana. Seminar Nasional. Reorientasi Pendidikan Kebencanaan Yogyakarta. 2009.

[40] Richard Baldwin and Eiichi Tomiura, thinking ahead about the trade impact of COVID-19 A CEPR Press VoxEU.org eBook, CEPR Press. ISBN: 9781-912179-28-2, 2020. Web: www.cepr.org

[41] Reza Rahman, Corporate Social Responsibility Antara Teori dan Kenyataan, Cetakan pertama, Yogyakarta: MedPres. 2009.

[42] Rice, Robert C., The Origin of Basic Economic Ideas and their Impact on New Order Policies, Bulletin of Indonesian Economic Studies, Vol 19, No. 2, Agustus 1983.

[43] Salim, Emil, Recollection of My Career, Bulletin of Indonesian Economic Studies, Vol 33 No. 1, April 1996.

[44] Sekaran Uma,Research Methodology for Business, A Multivariate Approach, Prentice hall Publisher, London. 2005.

[45] Sutton, J., and Tierney, K. Dissaster Preparedness: Concepts, Guidance and Research. University of Colorado. Colorado. 2006.

[46] Sri Trisnaningsih, Suparwati, Failasuf Herman Hendra, The Factors That Influence To Lecturers Performance With Motivation As An Intervening Variable, The Fourth UB international Consortium of Accounting, UB, Malang. 2012.

[47] Syahrial Ayub, Muh.Makhrus,dkk, Analisis Kesiapsiagaan Bencana Pada Guru Sekolah Dasar, 1Program Studi Pendidikan Fisika, Fakultas Keguruan dan Ilmu Pendidikan, Universitas Mataram, Mataram, Indonesia, Jurnal Penelitian Pendidikan IPA, 2017, doi: 10.29303/jppipa.v6i1.281 pp. 52-56.
[48] Swiss Re, Natural Catastrophe and Man-Made Disaster in 2011: Historic Losses Surface from Record Earthquake and Floods. Report prepared for Swiss Reinsurance Company Ltd. (Publication No. sigma No2/2012), Economic Research and Consulting, Switzerland. 2011.

[49] Twigg, J, Characteristics of a Disaster-Resilient Community: A Guidance Note. Disaster Risk Reduction Interagency Coordination Group, DFID. 95.Twigg, J. (2015). Disaster risk reduction. Good Practice Review 9. London: Humanitarian Practice Network. 2007.

[50] Undang Undang Nomor 40 Tahun 2007 Tentang Perseroan Terbatas. Undang-Undang Nomor 19 Tahun 2003 tentang Badan Usaha Milik Negara.

[51] Undang-Undang Nomor 20 Tahun 2008 tentang Usaha Mikro, Kecil dan Menengah.

[52] Widjaja Gunawan \& Yeremia Andi Pratama, Resiko Hukum \& Bisnis Perusahaan Tanpa CSR, Cetakan pertama, Jakarta: Forum Sahabat. 2008.

[53] World Health Organization, "Severe acute respiratory syndrome (SARS): Status of the outbreak and lessons for the immediate future", Geneva. 2003.

[54] World Health Organization, "Pandemi influenza preparedness and response: a WHO guidance document", Geneva. 2009.

[55] World Health Organization, A Systematic Review of Public Health Emergency Operations Centres (EOC). World Health Organization. WHO/HSE/GCR/2014.1. 2013. Retrieved from: http://apps.who.int/iris/bitstream/10665/99043/1/W HO_HSE_GCR_2014.1_eng.pdf119

[56] World Health Organization, "WHO MERS-CoV Global Summary and risk assessment", Geneva. 2016

[57] Yates, T., Vujcic, J., Joseph, M.L., \& Lantagne, D., Protocol: Short-term Hygiene Interventions in Emergency Response Situations: A Systematic Review and Impact Analysis. International Initiative for Impact Evaluation (3ie). 2015.

[58] Zhong, S., Clark, M., Hou, X.Y., Zang, Y., \& FitzGerald G. Progress and challenges of disaster health management in China: a scoping review.Global Health Action, 7, 2014, pp: 1- 9.121.

[59] Zwi, A., Spurway, K., Ranmuthugala, G., Marincowitz, R., Thompson, L., \& Hobday, K. Do Community Based Disaster Risk Management (CBDRM) Initiatives Reduce the Social and Economic Cost of Disasters? Protocol. EPPI-Centre, Social Science Research Unit, Institute of Education, University of London. 2013. 